\title{
PERTUMBUHAN DAN HASIL RUMPUT Brachiaria humidicola YANG DIBERI PUPUK KANDANG AYAM DAN NPK PADA TANAH BERPASIR (Growth and Yield of grass Brachiaria humidicola given chicken manure and NPK fertilizer on sandy soil)
}

\author{
Winarti, S., ${ }^{1)}$ dan Kristina ${ }^{2)}$ \\ ${ }^{1)}$ Dosen Jurusan Budidaya Pertanian Fakultas Pertanian Universitas Palangka Raya, \\ ${ }^{2)}$ Dosen Fakultas Peternakan Universitas Kristen Palangka Raya \\ Telpon : 08115208798 email : sihwinarti@pasca.upr.ac.id
}

Diterima : 13/03/2018

Disetujui : 10/04/2018

\begin{abstract}
This study aims to determine the growth and yield of grass Brachiaria humidicola on sandy soil. The design used Randomized Block Design arranged in a factorial pattern consists of two factors. The first factor was dosage of chicken manure consisting of three levels of 0,20 and $30 \mathrm{t} \mathrm{ha}^{-1}$ and the second factor was the dosage of N-P-K fertilizer consisting of four levels ie 0, 125, 250 and 500 $\mathrm{kg} \mathrm{ha}^{-1}$. The results showed that the application of manure with doses of $30 \mathrm{t} \mathrm{ha}^{-1}$ of grass Brachiaria humidicola grew tended to be higher, and N-P-K fertilizer with doses of $500 \mathrm{~kg} \mathrm{ha}^{-1}$ number of tiller per real clump (49,50 tillers) tends to be higher $(124,9 \mathrm{~cm}) \mathrm{N}-\mathrm{P}-\mathrm{K}$ fertilizer with dosage of $500 \mathrm{~kg} \mathrm{ha}^{-1}$, without manure obtained fresh plant weight grass Brachiaria humidicola highest $5.807 \mathrm{~g} \mathrm{~m}^{-2}$
\end{abstract}

Keywords: Brachiaria humidicola grass, manure and N-P-K, sandy soil

\begin{abstract}
ABSTRAK
Penelitian ini bertujuan untuk mengetahui pertumbuhan dan hasil rumput Brachiaria humidicola diberi pupuk kandang ayam dan N-P-K pada tanah berpasir . Rancangan yang digunakan adalah Rancangan Acak Kelompok faktorial terdiri dari dua faktor. Faktor pertama, yaitu dosis pupuk kandang kotoran ayam terdiri dari tiga aras, yaitu 0,20 dan $30 \mathrm{t} \mathrm{ha}^{-1}$ dan faktor kedua adalah dosis pupuk N-P-K terdiri dari empat aras, yaitu 0, 125, 250 dan $500 \mathrm{~kg} \mathrm{ha}^{-1}$. Hasil penelitian diperoleh bahwa pemberian pupuk kandang dengan dosis $30 \mathrm{t} \mathrm{ha}^{-1}$ tanaman rumput Brachiaria humidicola tumbuh lebih tinggi, dan pemberian pupuk NPK dengan dosis $500 \mathrm{~kg} \mathrm{ha}^{-1}$ jumlah anakan per rumpun nyata lebih banyak ( 49,50 anakan) dan tanaman tumbuh lebih tinggi $(124,9 \mathrm{~cm})$. Pemberian pupuk NPK dengan dosis $500 \mathrm{~kg} \mathrm{ha}^{-1}$ tanpa diberi pupuk kandang diperoleh bobot segar tanaman rumput Brachiaria humidicola paling tinggi 5,807 $\mathrm{g} \mathrm{m}^{-2}$.
\end{abstract}

\section{Kata kunci : rumput Brachiaria humidicola , pupuk kandang dan N-P-K, tanah berpasir}

\section{PENDAHULUAN}

Ketersediaan hijauan makanan ternak dengan mutu dan jumlah yang cukup merupakan syarat mutlak dalam usaha peternakan di Kota Palangka Raya. Sampai saat ini peternak di Kota Palangka Raya masih mengandalkan rumput yang tumbuh alami sebagai pakan ternak dengan kualitas yang relatif rendah. Agar usaha peternakan di Kota Palangka Raya dapat berkembang dengan baik diperlukan suatu upaya untuk mengembangkan hijauan makanan ternak dengan kualitas yang memadai dan jumlah yang cukup. 
Rumput Brachiaria humidicola, sebagai bahan pakan ternak merupakan hijauan unggul, dari aspek pertumbuhan, produktivitas dan nilai gizinya. Selain itu Brachiaria merupakan rumput yang palatabel dan dapat digunakan sebagai rumput potongan atau sebagai rumput untuk penggembalaan ternak ruminansia. Panen yang dihasilkan mencapai $8-20 \mathrm{t} \mathrm{ha}^{-1} \mathrm{th}^{-1}$ dan berdasarkan hasil penelitian Kusuma (2016) pemberian pupuk kandang kotoran ayam $40 \mathrm{t} \mathrm{ha}^{-1}$ mampu menghasilkan $6,5 \mathrm{~kg}$ per $\mathrm{m}^{-2}$ pada pemotongan pertama.

Bila melihat luas lahan di Kota Palangka Raya, budidaya rumput pakan ternak berpeluang untuk dikembangkan. Kenyataannya lahan di Kota Palangka Raya didominasi oleh tanah gambut dan tanah pasir dengan kesuburan tanah yang rendah. Tanah pasir adalah tanah dengan ukuran partikel besar. Tanah pasir memiliki kapasitas menyerap air rendah karena sebagian tersusun atas partikel berukuran 0,2 sampai $2 \mathrm{~mm}$. Unsur yang terkandung pada tanah berpasir adalah $\mathrm{P}$ dan $\mathrm{K}$ yang tidak larut sehingga tidak tersedia bagi tanaman, kandungan unsur $\mathrm{N}$ relatif rendah, fosfor $\pm 5,1-20,5 \mathrm{ppm}$, kandungan bahan organik $\pm 0,4-0,8 \%$, natrium sekitar $0,05-0,08 \%$ dan kalium sekitar 0,09 - 0,2 \% (PIGI, 2016). Hasil analisis kimia tanah pasir di lokasi pnelitian (Kristina 2017) bahwa pH 4,79 (masam); K2O $31,45 \mathrm{mg}$ per $100 \mathrm{~g}$ (sedang), P2O5 3,84 mg per $100 \mathrm{~g}$ (sangat rendah) dan N-total $0,75 \%$ (sangat rendah).

Upaya mengubah sifat tanah pasir agar sesuai untuk budidaya tanaman dapat ditambahkan pupuk organik berupa pupuk kandang. Pupuk kandang ayam merupakan pupuk organik sebagai sumber unsur nitrogen, serta berperan cukup besar untuk memperbaiki sifat fisik, biologis dan kimia tanah. Di dalam tanah, pupuk organik sebagian besar akan dimineralisasi sehingga unsur hara yang ada didalamnya akan larut dan tersedia bagi tanaman. Selain itu, pupuk organik berfungsi untuk memperbaiki struktur tanah karena pada proses mineralisasi dihasilkan produk yang mempunyai sifat sebagai perekat sehingga mampu mengikat butiran-butiran pasir menjadi lebih besar dan meningkatkan daya serap tanah terhadap air. Pupuk organik dapat meningkatkkan kehidupan mikroorganisme di dalam tanah, karena mikrorganime dapat memanfaatkan bahan organik sebagai makanannya.

Penambahan pupuk organik pada tanah pasir untuk meningkatkan kesuburan tanah belum mencukupi ketersediaan hara bagi tanaman, karena pupuk organik kandungan unsur haranya relatif sedikit dan lambat tersedia bagi tanaman. Oleh karena itu, diperlukan penambahan pupuk anorganik lengkap yang dan tersedia bagi tanaman, yaitu pupuk N-P-K. Pupuk N-P-K merupakan pupuk lengkap yang mengandung unsur hara esensial yang dibutuhkan tanaman dalam jumlah relatif banyak untuk memenuhi kebutuhan pertumbuhan dan perkembangan tanaman. Unsur $\mathrm{N}$ dan $\mathrm{P}$ merupakan unsur hara sangat dibutuhkan oleh tanaman dalam jumlah besar. Nitrogen merupakan unsur penting dalam pembentukan klorofil, protoplasma, protein, dan asam-asam nukleat. Nitrogen pada umunya diserap tanaman dalam bentuk NH4+ atau NO3-, yang dipengaruhi oleh sifat tanah, jenis tanaman dan fase pertumbuhan tanaman (Fahmi, 2010). Unsur $\mathrm{P}$ diperlukan untuk pembelahan sel, memacu pertumbuhan sistem parakaran, memperbaiki kualitas tanaman terutama makanan ternak, sebagai senyawa penyusun nukleoprotein dan berperan dalam menyimpan dan memindahkan energi ATP; $\mathrm{N}$ untuk memperbaiki pertumbuhan organ vegetatif dan pembentuk protein dan; K berperan sebagai ko-faktor enzim, membantu perkembangan akar, membantu proses fisiologi dalam tubuh tanaman serta memperkuat tanaman agar tahan terhadap serangan organisme pengganggu tanaman ( Hardjowigeno, 2007).

Berdasarkan permasalahan di atas perlu dilakukan penelitian mengenai pertumbuhan dan hasil rumput Brachiaria humidicola yang diberi pupuk organik kotoran ayam dan pupuk NPK pada tanah pasir. 


\section{BAHAN DAN METODE}

Penelitian dilaksanakan di Kebun Percobaan Fakultas Peternakan Universitas Kristen Palangka Raya, Jalan R.T.A Milono $\mathrm{Km}$ 8,5. Kelurahan Sabaru, Kota Palangka Raya, Kalimantan Tengah. Penelitian lapangan dilaksanakan selama 4 (empat) bulan dari bulan April sampai dengan bulan Juli 2016.

Bahan yang dipergunakan dalam penelitian adalah lahan tanah berpasir, pupuk kandang ayam, pupuk majemuk N-P-K mutiara 16:16:16, bibit rumput Brachiaria humidicola yang berasal dari tanaman induk yang ditanam dikebun percobaan Fakultas Peternakan Universitas Kristen Palangka Raya, serta bahan-bahan lain yang digunakan untuk analisis tanah.

Penelitian ini menggunakan Rancangan Acak Kelompok (RAK), dengan pola faktorial terdiri dari 2 (dua) faktor perlakuan. Faktor pertama yaitu dosis pupuk kandang ayam terdiri dari 3 (tiga) taraf perlakuan, yaitu: $0\left(\mathrm{t}_{0}\right), 20\left(\mathrm{t}_{1}\right)$ dan $30\left(\mathrm{t}_{2}\right) \mathrm{t} \mathrm{ha}^{-1}$ atau 0,10 dan $15 \mathrm{~kg}$ per petak. Faktor kedua adalah pupuk NPK majemuk 16:16:16 terdiri dari 4 (empat) taraf yaitu: 0, 125, 250 dan 500 $\mathrm{kg}$ per ha atau 0 (kontrol), 62,5; 125; dan $250 \mathrm{~g}$ per petakdan diulang sebanyak 4 (empat) kali sehingga terdapat 48 satuan percobaan.

Satuan percobaan berukuran $2,0 \times 2,5$ $\mathrm{m}$, jarak tanam $50 \times 50 \mathrm{~cm}$, dan setiap satuan percobaan terdiri dari 20 rumpun tanaman. Untuk pengukuran pertumbuhan tanaman dilakukan pada 3 (tiga) rumpun dan untuk pengamatan hasil dilakukan per $\mathrm{m}^{-2}$ ( empat rumpun per petak). Data yang diperoleh dianalisis ragam dengan uji $\mathrm{F} 5 \%$ dan $1 \%$ dan bila terdapat perbedaaan antara perlakuan dilanjutkan dengan uji BNJ $5 \%$.

Pupuk kandang ayam diberikan sebelum tanam, sesuai dosis perlakuan dicampur secara merata pada setiap petak satuan percobaan, dan diinkubasi selama 2 (dua) minggu, setelah masa inkubasi dilakukan penanaman. Bibit rumput
Brachiaria humidicola berupa anakan dengan tinggi $\pm 15 \mathrm{~cm}$, dengan 3 (tiga) bibit per lobang, jarak tanam $50 \times 50 \mathrm{~cm}$.

Pemupukan N-P-K $16: 16: 16$ dilakukan dengan dosis sesuai perlakuan, 0 , 62,$5 ; 125$ dan $250 \mathrm{~g}$ per petak. Pemupukan dilakukan dalam 3 (tiga) tahap tahap pertama diberikan bersamaan dengan waktu tanam, tahap ke-2 (dua) diberikan setelah tanaman rumput berumur 2 minggu dan tahap ke-3 (tiga) diberikan setelah tanaman berumur 4 minggu. Pemanenan dilakukan pada umur 60 hari setelah tanam (hst) dengan cara memotong bagian bawah batang sepanjang 10 $\mathrm{cm}$. Variabel Penelitian :

a. Tinggi tanaman $(\mathrm{cm})$ diukur pada umur 10 , 20, 30, 40 dan 50 hari setelah tanam (hst) dengan cara dirangkum dari permukaan tanah sampai keujung daun paling tinggi yang dinyatakan dalam satuan sentimeter $(\mathrm{cm})$;

b. Jumlah anakan diamati 5 (lima) kali pada umur 10, 20, 30, 40 dan 50 hari setelah tanam (hst);

c. Bobot segar hijauan per $\mathrm{m}^{2}$.

\section{HASIL DAN PEMBAHASAN Pertumbuhan Tinggi Tanaman Rumput Beha}

Pertumbuhan tinggi tanaman diamati pada umur 10, 20, 30, 40 dan 50 hari setelah tanam (hst). Hasil pengamatan tinggi tanaman disajikan pada Gambar 1.

Berdasarkan Gambar 1 dan Tabel 1 nampak bahwa semakin tinggi dosis pupuk kandang, tanaman Brachiaria humidicola tumbuh lebih tinggi, demikian juga pemberian pupuk N-P-K memberikan perbedaan pertumbuhan tinggi tanaman yang nyata. Pemberian pupuk kandang $20 \mathrm{t}$ per ha 1 cenderung meningkatkan tinggi tanaman sekitar 5,4\%, dan dengan penambahan dosis pupuk kandang menjadi $30 \mathrm{t} \mathrm{ha}^{-1}$ tinggi tanaman meningkat $10,8 \%$ dibandingkan dengan yang tanpa diberi pupuk kandang. 

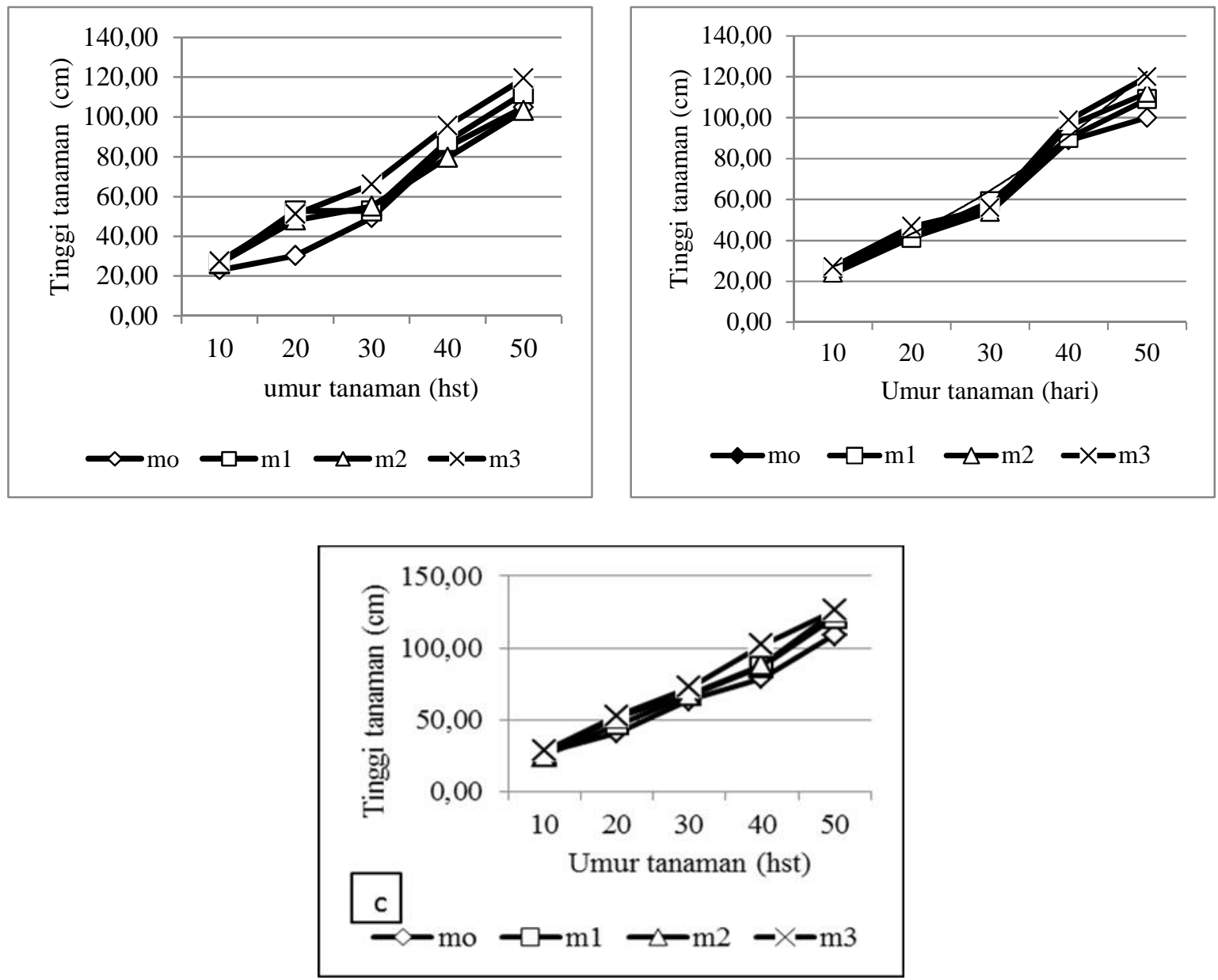

Gambar 1. Pertumbuhan tinggi tanaman rumput Brachiaria humidicola tanpa diberi pupuk kandang (a), 20 (b) dan $30 \mathrm{t} \mathrm{ha}^{-1}$ pupuk kandang (c) tanpa diberi/ 0 (mo), 125 (m1), 250 (m2) dan $500 \mathrm{~kg} \mathrm{ha}^{-1}$ pupuk N-P-K (m3)

Tabel 1. Tinggi tanaman Brachiaria humidicola $(\mathrm{cm})$ yang diberi pupuk kandang dan pupuk NPK dengan dosis yang berbeda pada umur 50 hari setelah tanam

\begin{tabular}{lcccc}
\hline \multicolumn{1}{c}{ Dosis pupuk } & \multicolumn{3}{c}{ Dosis pupuk kandang ayam $\left(\mathrm{t} \mathrm{ha}^{-1}\right)$} & \multirow{2}{*}{ Rata-rata } \\
\cline { 2 - 4 } NPK $\left(\mathrm{kg} \mathrm{ha}^{-1}\right)$ & 0 & 20 & 30 & $112,3 \mathrm{a}$ \\
\hline 0 & 108,0 & 113,7 & 115,3 & $117,0 \mathrm{ab}$ \\
125 & 112,3 & 115,3 & 123,3 & $119,2 \mathrm{ab}$ \\
250 & 106,7 & 122,3 & 128,7 & $124,9 \mathrm{~b}$ \\
500 & 122,3 & 122,0 & 130,3 & 11,02 \\
\hline Rata-rata & $112,3 \mathrm{a}$ & $118,3 \mathrm{ab}$ & $124,4 \mathrm{~b}$ & \\
\hline BNJ 5\%: & & 9,70 & & \multirow{2}{*}{}
\end{tabular}

Keterangan : Berdasarkan analisis ragam dosis pupuk kandang dan N-P-K secara mandiri teruji nyata. Angka-angka yang diikuti huruf yang sama pada baris dan kolom yng sama tidak menunjukkan perbedaan yang nyata pada uji BNJ $5 \%$. 

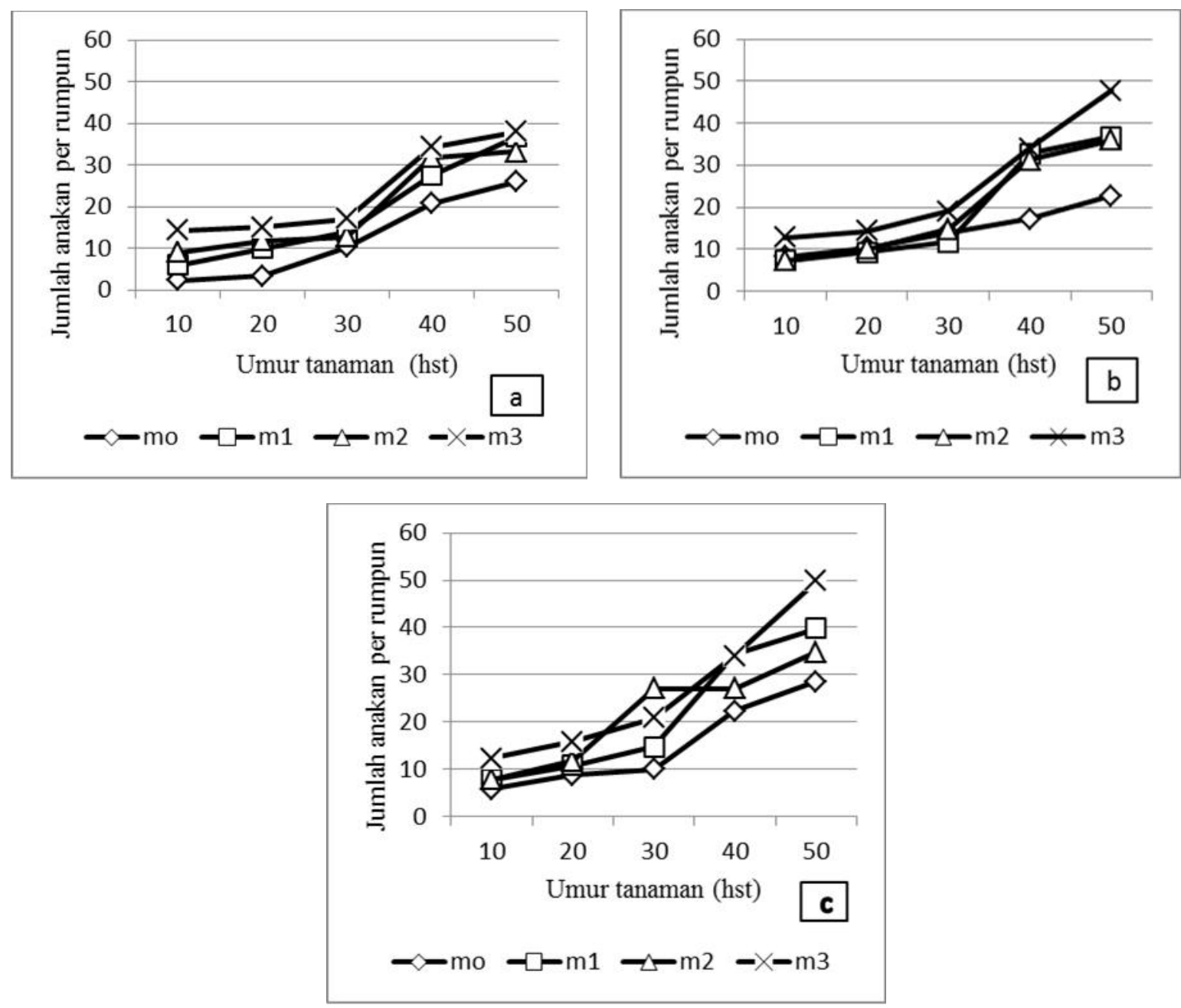

Gambar 2. Jumlah anakan per rumpun rumput Brachiaria humidicola tanpa diberi pupuk kandang (a), 20 (b) dan $30 \mathrm{t} \mathrm{ha}^{-1}$ pupuk kandang (c) tanpa diberi / 0 (mo), 125 (m1), 250 (m2) dan $500 \mathrm{~kg} \mathrm{ha}^{-1}$ pupuk N-P-K (m3)

Peningkatan pertumbuhan tinggi tanaman disebabkan karena penambahan pupuk kandang dapat memperbaiki sifat fisik tanah diantaranya terbentuknya agregat tanah yang relatif kompak sehingga meningkatkan kemampuan menahan air, selain itu pupuk kandang juga mampu menyediakan unsur hara makro dan mikro walaupun dalam jumlah yang relatif terbatas.

Berdasarkan hasil uji nilai rata-rata (Tabel 1) tinggi tanaman umur $50 \mathrm{hst}$, pemberian pupuk kandang dengan dosis yang semakin tinggi yaitu $30 \mathrm{t} \mathrm{ha}^{-1}$ tinggi tanaman meningkat secara nyata dibandingkan dengan kontrol (tanpa diberi pupuk kandang). Menurut Knuti dkk., (1970 dalam Harjowigeno 2007) setiap ton pupuk kandang mengandung $5 \mathrm{~kg} \mathrm{~N}, 3 \mathrm{~kg} \mathrm{P}_{2} \mathrm{O}_{5}$ dan $5 \mathrm{~kg} \mathrm{~K}_{2} \mathrm{O}$ serta unsur esensial lain dalam jumlah yang relatif kecil. Oleh karena itu penambahan pupuk kandang yang mengadung unsur hara makro maupun mikro dapat memacu pertumbuhan tinggi tanaman.

Pemberian pupuk N-P-K dengan dosis yang semakin meningkat cenderung meingkatkan pertumbuhan tinggi tanaman dan pada penambahan dosis pupuk N-P-K menjadi $500 \mathrm{~kg} \mathrm{ha}^{-1}$ tinggi tanaman rumput Brachiaria 
humidicola meningkat secara nyata dibandingkan dengan tanpa diberi pupuk N-P$\mathrm{K}$. Unsur hara $\mathrm{N}, \mathrm{P}$ dan $\mathrm{K}$ merupakan unsur hara makro yang sangat dibutuhkan untuk pertumbuhan tanaman, sehingga perlu penambahan pupuk dengan dosis yang cukup tinggi agar pertumbuhan tanaman yang lebih baik. Nitrogen sebagai bahan penyusun protein tanaman, klorofil dan asam nukleat sehingga dapat memacu produksi tanaman (Sigar, $d k k ., 2014$ )

\section{Jumlah Anakan per Rumpun}

Jumlah anakan per rumpun diamati pada umur 10, 20, 30, 40 dan 50 hari setelah tanam (hst). Hasil pengamatan jumlah anakan per rumpun disajikan pada Gambar 2 dan hasil uji nilai tengah disajikan pada Tabel 2.

Semakin tinggi dosis pupuk kandang dan pupuk N-P-K yang diberikan (Gambar 2) jumlah anakan per rumpun semakin banyak. Namun demikian hasil uji nilai rata-rata (BNJ 5\%) terhadap jumlah anakan per rumpun, pemberian pupuk kandang ternyata tidak menunjukkan perbedaan yang nyata, tetapi pemberian pupuk N-P-K meningkatkan jumlah anakan rumput Brachiaria humidicola secara nyata. Pemberian dosis pupuk N-P-K $500 \mathrm{~kg} \mathrm{ha}^{-1}$ diperoleh jumlah anakan tertinggi, bahkan bila dibandingkan dengan kontrol mampu meningkatkan jumlah anakan sampai 97\% (Tabel 2).

Nitrogen, fosfor, dan kalium merupakan unsur hara makro yang berperan sebagai penyusun asam nukleat sehingga dapat memacu pertumbuhan tanaman (Sigar, $d k k$., 2014). Nitrogen merupakan unsur penting dalam pembentukan klorofil, protoplasma, protein, dan asam-asam nukleat. Klorofil, protoplasma, protein, dan asam-asam nukleat, berperan penting dalam pertumbuhan dan perkembangan jaringan tanaman (Brady dan Weil, 2002). Fosfor merupakan komponen penting penyusun senyawa ATP, yang berperan dalam transfer energi (Gardner $d k k$., 1991).
Tabel 2. Jumlah anakan per rumpun Brachiaria humidicola yang diberi pupuk kandang dan pupuk NPK dengan dosis yang berbeda pada umur 50 hari setelah tanam

\begin{tabular}{|c|c|c|c|c|}
\hline \multirow{2}{*}{$\begin{array}{c}\text { Dosis } \\
\text { pupuk } \\
\text { NPK } \\
\left(\mathrm{kg} \mathrm{ha}^{-1}\right)\end{array}$} & \multicolumn{3}{|c|}{$\begin{array}{l}\text { Dosis pupuk kandang ayam } \\
\left(\mathrm{t} \mathrm{ha}^{-1}\right)\end{array}$} & \multirow{2}{*}{$\begin{array}{l}\text { Rata- } \\
\text { rata }\end{array}$} \\
\hline & 0 & 20 & 30 & \\
\hline 0 & 26,00 & 22,75 & 26,50 & $25,08 \mathrm{a}$ \\
\hline 125 & 34,75 & 36,75 & 37,25 & $36,25 \mathrm{~b}$ \\
\hline 250 & 35,25 & 36,00 & 39,25 & $36,83 \mathrm{~b}$ \\
\hline 500 & 38,00 & 47,75 & 49,50 & $49,50 \mathrm{c}$ \\
\hline $\begin{array}{l}\text { Rata- } \\
\text { rata }\end{array}$ & $33,50 \mathrm{a}$ & $35,81 \mathrm{a}$ & $38,13 \mathrm{a}$ & $\begin{array}{l}\text { BNJ : } \\
8,38\end{array}$ \\
\hline
\end{tabular}

Keterangan : Berdasarkan analisis ragam dosis pupuk kandang dan N-P-K secara mandiri teruji nyata. Angkaangka yang diikuti huruf yang sama tidak menunjukkan perbedaan yang nyata pada uji BNJ 5\%.

Selain itu, ketersediaan unsur $\mathrm{P}$ dapat memacu perkembangan akar (Hardjowigeno, 2007) sehingga penyerapan hara dapat berjalan lebih maksimal. Dengan tersedianya unsur hara, air dan cahaya matahari, proses fotosintesis dapat berlangsung dengan baik, demikian pula proses respirasi. Berlangsungnya proses metabolisme dengan baik, energi yang dihasilkan mencukupi untuk pembentukan organ tanaman baru yaitu jumlah anakan tanaman lebih banyak. Kalium berperan dalam mengendalikan aktivitas enzim yang berperan penting dalam proses metabolisme, transportasi asimilat, sintesis protein dan pati, perkembangan sel dan aktivitas stomata (Marschner, 1986; Salisbury dan Ross, 1992). Menurut Wang et al. (2007) dan Horner (2008 dalam Fahmi et al. (2010) bahwa kondisi pertumbuhan tanaman yang baik akibat tercukupinya hara $\mathrm{N}$ akan menyebabkan tanaman mampu menyerap $\mathrm{P}$ lebih efektif. Dengan demikian penambahan pupuk NPK dapat memacu pertumbuhan tanaman dan memperbanyak jumlah anakan per rumpun. 
Tabel 3. Hasil uji nilai tengah bobot segar (g) rumput Brachiaria humidicola per $\mathrm{m}^{2}$ yang diberi pupuk kandang dan pupuk NPK dengan dosis yang berbeda

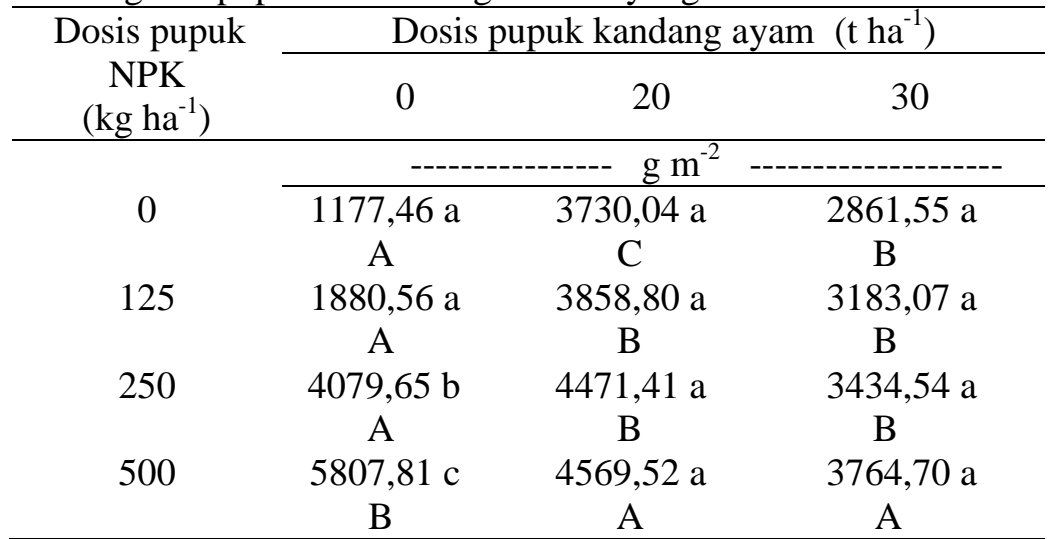

Keterangan: Berdasarkan analisis ragam dosis pupuk kandang dan interaksi pupuk kandang dan dosis N-P-K teruji nyata. Angka-angka yang diikuti huruf yang sama tidak menunjukkan perbedaan yang nyata pada uji BNJ 5\%. Huruf kecil dibaca arah vertikal, huruf kapital dibaca arah horizontal

\section{Bobot Tanaman Rumput Brachiaria humidicola}

Hasil uji nilai tengah bobot segar per rumpun rumput Brachiaria humidicola disajikan pada Tabel 3.

Pemberian pupuk kandang berpengaruh nyata pada yang tanpa diberi pupuk NPK, dan diberi pupuk NPK dengan dosis 125, dan 250 $\mathrm{kg} \mathrm{ha}^{-1}$. Pemberian pupuk kandang $20 \mathrm{t} \mathrm{ha}^{-1}$ sudah dapat meningkatkan bobot segar tanaman rumput Brachiaria humidicola. Pemberian pupuk kandang pada tanah berpasir mampu memperbaiki sifat fisik, kimia dan biologi tanah, yakni kemampuan menahan air lebih baik, tanah menjadi lebih kompak, menambah unsur hara terutama $\mathrm{N}$, dan unsur hara lain walaupun dalam jumlah kecil, dan memperkaya organisme dekomposer.

Tanpa pemberian pupuk kandang, tetapi diberi pupuk N-P-K dengan dosis yang semakin tinggi mampu meningkatkan bobot rumput Brachiaria humidicola per $\mathrm{m}^{2}$ secara nyata, bobot segar tertinggi diperoleh pada pemberian pupuk N-P-K $500 \mathrm{~kg}$ per $\mathrm{m}^{-2}$. Sedangkan yang diberi pupuk kandang, pemberian pupuk N-P-K tidak memberikan perbedaan yang nyata (Tabel 3). Seperti dijelaskan di atas bahwa pemberian pupuk N$\mathrm{P}-\mathrm{K}$ secara bersama-sama mampu meningkatkan tinggi tanaman dan jumlah anakan per rumpun. Dengan bertambah tinggi dan jumlah anakan, akan berpengaruh terhadap bobot tanaman. Hasil penelitian Fahmi et al. (2010) menyatakan bahwa pemberian $\mathrm{N}$ dan $\mathrm{P}$ dalam bentuk pupuk secara bersama-sama menyebabkan adanya interaksi positif terhadap berat kering total tanaman jagung pada tanah latosol. Selanjutnya menurut Hardjowigeno (2007) unsur $\mathrm{K}$ berfungsi untuk mengaktifkan enzim, mengatur membukanya stomata, serta membantu penyerapan unsur hara lain.

\section{KESIMPULAN}

1. Pemberian pupuk kandang dengan dosis $30 \mathrm{t} \mathrm{ha}^{-1}$ tanaman rumput Brachiaria humidicola tumbuh lebih tinggi $(124,4$ $\mathrm{cm}$ ), dan pemberian pupuk N-P-K dengan dosis $500 \mathrm{~kg} \mathrm{ha}^{-1}$ jumlah anakan per rumpun nyata lebih banyak ( 49,50 anakan) dan tanaman tumbuh lebih tinggi $(124,9 \mathrm{~cm})$.

2. Pemberian pupuk N-P-K dengan dosis 500 $\mathrm{kg} \mathrm{ha}{ }^{-1}$ tanpa diberi pupuk kandang diperoleh bobot tanaman rumput Brachiaria humidicola paling tinggi 5807 $\mathrm{g} \mathrm{m}^{-2}$, 


\section{DAFTAR PUSTAKA}

Brady N.C., dan R.R. Weil. 2002. The Nature and Properties of Soils. $13^{\text {th }}$ edition. Upper Saddle River, New Jersey.

Fahmi A., Syamsudin, S.N.H. Utami dan B. Radjagukguk. 2010. Pengaruh interaksi hara nitrogen dan fosfor terhadap pertumbuhan tanaman jagung (Zea mays L) pada tanah Regosol dan Latosol. Jurnal Ilmu-Ilmu Hayati, Berita Biologi Vol 10 (3) : 297 $-304$.

Gardner, F.P., R.B Perarce, and R.L. Mitchell. 1991. Physiology of Crop Plants. Iowa State University Press, Ames, IA.

Gunadi S, 2002. Teknologi Pemanfaatan Lahan Marginal Kawasan Pesisir. Jurnal Teknologi Lingkungan Vol 3 (3) : $232-236$.

Hardjowigeno S. 2007. Ilmu Tanah. Akademika Pressindo, Jakarta.

Kusuma M.E. 2016. Efektifitas pemberian dosis pupuk kotoran ternak ayam terhadap produksi rumput Brachiaria humidicola pada pemotongan pertama dan kedua. Jurnal Ilmu Hewani Tropika Vol 5 (1) : 1 - 6.
Kristina. 2017. Pemanfaatan pupuk kandang ayam dan pupuk majemuk NPK pada tanah berpasir terhadap pertumbuhan dan hasil tanaman rumput beha (brachiaria humidicola). Tesis S-2. Program Pascasaarjana UPR.

Marcshner H. 1986. Mineral Nutrition of Higher Plants. Acd. Press. London.

Pusat Ilmu Geografi Indonesia (PIGI). 2016. Tanah Pasir : Pengertian, Karakteristik, dan Pemanfaatannya. Ilmu Geografi.com. Diakses 28 Februari 2018.

Salisbury, F.B., dan C.W. Ross. 1995a. Fisiologi Tumbuhan. Terjemahan dari : Plant Physiology. ITB, Bandung.

Sigar N.V.F, D.A. Kaligis, W.B. Kaunang dan S.S. Malalantang. 2014. Pengaruh pemberian pupuk N-P-K terhadap hasil bahan kering dan protein kasar rumput Brachiaria humidicola cv. Tully dan Pennisetum purpureum cv. Mott. Jurnal zootek Vol 34 (2) : 109 113 